\title{
THE MYSTERY OF THE TOWN OF NINGI (OR THE INVISIBLE CHRISTMAS)
}

\section{Seno Gumira Ajidarma}

That Christmas Eve the church bells pealed, resounding to every corner of the town of Ningi. I heard the echo of a choir singing 'Holy Night', and in the sky I saw the stars shining brightly. Human life is so fleeting-but shouldn't we always believe that there is something of enduring value in this life?

On Christmas Eve, in the town of Ningi, I walked along the empty street thinking about the meaning of 'fleeting' and 'enduring'. I would never have thought about such things if I hadn't come to Ningi. You see, I'm just a simple census collector. My life is dry and boring. I only associate with figures. My work is limited to counting how many family members there are in a house. So I count people from house to house, until I've collected the total population of a town, year by year.

At a certain time in my life as a census collector I was assigned to the town of Ningi, a town I had no idea would wake me up from my sleepy life that had gone on for so long. You see, counting people over and over again, in town after town, is really very simple, and incredibly monotonous. From one town to another I just saw humans producing descendants. Year after year they produced descendants and used up all their land and ended up quarreling with each other.

In Ningi I found something entirely different. In Ningi, from year to year the population was decreasing. It was very strange. At a time when the world was frowning with worry because of the frightening, rapid growth in population, the population of Ningi was shrinking. When I dug out the archives, the records for 1974 showed a total population of 668,771 . But when I counted again in 1978 it seemed the population had shrunk to 329,271 people. Where had the other 359,500 gone to? It 
was very peculiar. But in fact it wasn't the matter of that decrease that made me feel strange. ${ }^{1}$

I'd better tell you how my sleepy life as a census collector was woken up.

The first time I entered a house in Ningi I found something mysterious. I counted everyone in the house. There were seven occupants.

'So, there are seven of you altogether, are there lady?'

'There's really eight of us.'

'I see. One of you died, is that right?'

'No, he's not dead. He was actually killed, but he's not dead yet.'

'Where is he?'

'He's here, with us.'

'Where?'

She pointed to the dinner table. I looked in the direction she was pointing. I saw that there was rice on a plate, and prawn chips and tempe. I saw a spoon and fork moving by themselves, as though someone was holding them, and putting the food into his mouth. I gaped.

'Who is it?'

'That's Adelino, our brother who was arrested, interrogated and beaten to death. But he's still here. See for yourself.'

I saw a prawn chip floating through the air by itself, heard a crunching sound, and then it disappeared. Maybe Adelino had swallowed it.

'So you see, there's really eight of us.'

I left that house in a daze. With my own eyes I'd seen water being poured, a glass being lifted, the water being drunk and disappearing, as if someone really had drunk it.

I'm only a census collector, a minor official, a problem like that was far too weighty for my brain. I hurried into another house, trying to forget the incident in the previous one. But the fact was, it seemed Ningi was a very mysterious town. In every house I entered there were always those invisible beings. Again and again I saw spoons and forks moving by themselves to pick up food, glasses emptying into invisible mouths and heard the sound of people splashing about as they bathed, but the people doing it, who were really dead, were invisible. I could only see the water dipper going up and down with nobody holding it. It was astonishing.

So, you could say that the population of that town consisted of visible people and invisible people. Whenever I walked along the roads there, I'd see pairs of thongs walking along by themselves, or a motor bike starting up suddenly and taking off, or a car speeding by with no driver. In the market you could hear the hustle and bustle of

\footnotetext{
${ }^{1}$ The figures in this short story refer to G. J. Aditjondro, Prospects for Development of East Timor After the
} Capture of Xanana Gusmao, Hayam Waruk No. 1 Th V111/1993, pp. 62-67. 
visible people and invisible people. It seemed the people of Ningi were used to living with invisible people, even though they apparently never spoke.

The Ningi people always referred to the invisible ones as 'our brothers and sisters', with cold expressions on their faces. They didn't seem to be too sad that their brothers and sisters were invisible. Maybe they were, but they'd got used to it. To be precise, they were so used to being sad that they didn't look as though they were sad at all. The faces of the visible people were very bitter, and the expression in their eyes was full of suffering-nevertheless they never gave the impression that they were sad.

I didn't know what had happened in the past in Ningi. In that town there weren't any historical records. The history books that I saw in the library were more like fairy tales. How could the people of Ningi get to know themselves? History doesn't get wiped out, but historical records can be destroyed. As a census collector I only found figures from the past, but what could figures tell you?

According to my experience as a census collector, if the rate of population growth in Ningi was normal, that is nine percent per annum based on date from 1970-1973, then in 1980 the population should have been 667,100 . It turned out that when I counted from house to house the total was only 555,350 people. I was very surprised. There was no epidemic, no war, no large-scale exodus, but where had those 111,750 human being disappeared to ${ }^{2}$ In one village at the edge of town, which had once had a population of $9,607,5,021$ of the population had gone missing-was it they who'd become the invisible beings, the wandering spirits?

Of course I heard whispers that at night masked gangs prowled around, who forced their way into houses and carried the occupants away. ${ }^{3}$ According to those whispers, the people who were abducted didn't always come back. Those who did were invisible and couldn't speak. Strangely, the people they lived with weren't too surprised. Apparently they believed that if people didn't die from natural causes, for example if they were murdered, their souls wouldn't depart. Although I'm just a simple census collector, in my free time I take the opportunity to read anthropological studies about my work environment. From these I found out that these Ningi people believe that, as spirits, those dead souls are sacred, but they can still roam around close to living people. ${ }^{4}$

After some years of living in the town of Ningi, I became used to the invisible people, although I could never completely understand their meaning. For a census collector like me, whose task is just counting, counting and more counting, the most important thing is reporting growth figures. So I also have to record that from year to year the population of Ningi decreased, and on the other hand the number of invisible people increased. Therefore, if it's really counted correctly, the population of Ningi was actually increasing, it's just that so many of them were invisible-halfway between existing and not existing.

\footnotetext{
2 This figure of 111,750 is a correction. Aditjondro wrote it 112,000 .

${ }^{3}$ See "The Mystery of Siluman with the Curly Hair', in Jakarta Jakarta, no. 288, 4-10 January 1992, pp. 100101.

${ }^{4}$ David Hicks, The Spirits of the Tetum People in East Timor, Pustaka Sinar Harapan, Jakarta 1985, p. 130.
} 
178 Seno Gumira Ajidarma

When I returned to the very first house I'd visited and went inside, there was only one occupant remaining. The other seven were nowhere to be seen. When she had a meal at the table she appeared to be alone, but on either side of her spoons and forks clattered as they made contact with plates. Many objects were flying around and thongs were walking about by themselves in that house. That's what went on in every corner of Ningi.

From year to year the population continued to dwindle. I knew that one day it would disappear completely and be replaced by newcomers. On the road I often passed or collided with invisible people. They were anywhere at any time. Whenever I passed the cemetery, I heard the voices of invisible people moaning and groaning. Sometimes I also passed invisible people who kept dripping blood. Of course all I saw were drops of blood coming from God knows where, accompanied by the sound of groans.

On the footpaths, on the soccer field, at the market and beside the beach I often came upon dripping blood moving around by itself. It was the blood of invisible people whose lives were deliberately terminated. Yet it seemed they couldn't die, they were still there, existing and moving like ordinary people. As a good census collector, I also recorded the growth in the number of invisible people from house to house. In many of the houses I visited, they were the only occupants. Glasses and brooms moved, and television sets turned on, all by themselves. My God, if there's a good comedy show, how do they laugh? These invisible people can't make any sound except to groan and moan and lament.

So far, I've been living in Ningi for fifteen years and my life is really lonely. By day I work counting people, and at night I don't dare leave the house because there are gangs of masked men like ninjas. Actually, the theory is, they won't come into my house because I'm only an outsider. During all this time those gangs of masked men have only entered the homes of the local Ningi people. That's the way it all happened, until now the population of Ningi has disappeared completely.

On Christmas Eve, I was the only person to be seen in the town. The church bells pealed, resounding throughout the town. I heard the echo of a choir singing 'Holy Night', and in the sky I saw stars shining brightly. I celebrated Christmas with the invisible people. Maybe I should write a poem about all this. Maybe I'll call it 'The Invisible Christmas'. Actually I'm just a simple census collector, but I'm allowed to ponder the meaning of life which is both fleeting and enduring, aren't I?

Jakarta, 15 December 1993

From Seno Gumira Ajidarma, "The Mystery of the Town of Ningi (or The Invisible Christmas)," Eyewitness, trans. Jan Lingard (Sydney, Australia: ETT Imprint, 1995), pp. 103-110.

(C) Seno Gumira Ajidarma 1995. Translation Jan Lingard 1995. Reprinted with permission from ETT Imprint. 